\title{
A contribution to the myriapod fauna of the Omsk Area, Siberia, Russia (Myriapoda: Diplopoda, Chilopoda)
}

\section{К изучению фауны многоножек Омской области, Сибирь, Россия (Myriapoda: Diplopoda, Chilopoda)}

\author{
P.S. Nefediev ${ }^{1}$, S.Yu. Knyazev', G.Sh. Farzalieva ${ }^{3}$, I.H. Tuf ${ }^{4}$ \\ П.С. Нефедьев ${ }^{1}$, С.Ю. Князев ${ }^{2}$, Г.Ш. Фарзалиева ${ }^{3}$, И.Х. Ту $\phi^{4}$
}

\footnotetext{
${ }^{1}$ Altai State University, Lenina Avenue, 61, Barnaul 656049 Russia. E-mail: p.nefediev@mail.ru

${ }^{2}$ Omsk State Pedagogical University, Tukhachevskogo Embankment, 14, Omsk 644099 Russia. E-mail: statusomgpu@gmail.com

${ }^{3}$ Perm State University, Bukireva Street, 15, Perm 614600 Russia. E-mail: g.farzalieva@yandex.ru

${ }^{4}$ Palacký University, Šlechtitelů, 27, Olomouc 77900, Czech Republic. E-mail: ivan.tuf@upol.cz

${ }^{1}$ Алтайский государственный университет, проспект Ленина, 61, Барнаул 656049 Россия.

2 Омский государственный педагогический университет, набережная им. Тухачевского, 14, Омск 644099 Россия.

${ }^{3}$ Пермский государственный национальный исследовательский университет, ул. Букирева, 15, Пермь 614600 Россия.
}

KEY WORDS: Julidae, Geophilidae, Lithobiidae, fauna, new records, Omsk Area, Siberia.

КЛЮЧЕВЫЕ СЛОВА: Julidae, Geophilidae, Lithobiidae, фауна, новые находки, Омская область, Сибирь.

ABSTRACT. Based on fresh collections in the Omsk Area, southwestern Siberia, the first list of myriapod species is given which comprises at least 7 species from 4 genera, 3 families, 3 orders (Julida, Geophilomorpha and Lithobiomorpha) and two classes (Diplopoda and Chilopoda). The millipede genus Brachyiulus Berlese, 1884), the species B. jawlowskii Lohmander, 1928 , and the family Julidae, the centipede genus Geophilus Leach, 1814, the species G. proximus C.L. Koch, 1847 , and the family Geophilidae are reported from the Omsk Area for the first time. New records are also presented of the following Lithobiidae centipedes from the Omsk Area: the genera Hessebius Verhoeff, 1941 and Lithobius Leach, 1814, subgenera Monotarsobius Verhoeff, 1905 and Ezembius Chamberlin, 1919, and the species L. (M.) curtipes C.L. Koch, 1847, L. (E.) princeps Stuxberg, 1876 and L. (E.) proximus Sseliwanoff, 1878, while L. (M.) insolens Dányi et Tuf, 2012 is new to the fauna of Russia. Remarks are provided for all species encountered, all being mapped as well.

РЕЗЮМЕ. По свежему материалу из Омской области (Юго-Западная Сибирь) впервые приводится список видов многоножек, включающий как минимум 7 видов из 4 родов, 3 семейств, 3 отрядов (Julida, Geophilomorpha и Lithobiomorpha) и двух классов (Diplopoda и Chilopoda). Диплоподы рода Brachyiulus Berlese, 1884, вид B. jawlowskii Lohmander, 1928, семейство Julidae, губоногие рода Geophilus Leach, 1814, вид G. proximus C.L. Koch, 1847 и семейство Geophilidae впервые указаны для Омской области. Представлены и новые находки костянок из семейства Lithobiidae из Омской обла- сти: рода Hessebius Verhoeff, 1941 и Lithobius Leach, 1814, подрода Monotarsobius Verhoeff, 1905 и Ezembius Chamberlin, 1919, а также виды L. (M.) curtipes C.L. Koch, 1847, L. (E.) princeps Stuxberg, 1876 и L. (E.) proximus Sseliwanoff, 1878, тогда как вид $L$. (M.) insolens Dányi et Tuf, 2012 - новый для фауны России. Для всех видов приведены замечания и картирование находок.

\section{Introduction}

The Omsk Area is located in southwestern Siberia and shares borders with the Tyumen Area to the west and north, to the Tomsk and Novosibirsk areas in the east, as well as an international border to Kazakhstan in the south. The Omsk Area, part of the West Siberian Plain, spans about $600 \mathrm{~km}$ north to south and $300 \mathrm{~km}$ west to east. The main waterways in this area are the Irtysh River and its larger tributaries. The northern parts of the area support marshy taiga (= boreal) forest which are gradually replaced by forested or grassland plains in the south. The area is subjected to continental climate, with cold and snowy winters, and hot and dry summers.

The Omsk Area has hitherto remained a complete lacuna as regards myriapodological studies. Recently, the second co-author collected Myriapoda using the standard soil sampling techniques practiced in Russia [Ghilarov, 1987] by taking 5 soil samples per study site, hand-sorting each $10 \mathrm{~cm}$ layer down to $50 \mathrm{~cm}$ until fauna penetration, with the sample area totaling $1 / 4 \mathrm{~m}^{2}$. The material treated herein has been shared between the collections of the following institutions: Altai State University, Barnaul, Russia (ASU), Omsk State Peda- 
gogical University (OSPU), Perm State University, Perm, Russia (PSU) and Zoological Museum of the Moscow Lomonosov State University, Moscow, Russia (ZMUM), as indicated in the text. The total myriapod material studied amounted to 108 specimens.

\section{Taxonomic part}

\section{Order JULIDA \\ Family JULIDAE}

Brachyiulus jawlowskii Lohmander, 1928 Map 1.

MATERIAL EXAMINED ( 3 우 from a single locality). 1 ㅇ (ZMUM), Russia, Siberia, Omsk Area, Omsk City, Omsk Regional Station of Young Naturalists, $54^{\circ} 58^{\prime} 50^{\prime \prime} \mathrm{N}, 73^{\circ} 18^{\prime} 10^{\prime \prime} \mathrm{E}$, steppe meadow, soil samples (20-30 cm deep), 15.08.2016; 1 \& (ASU), 1 + (OSPU), same locality, soil samples (20-30 cm deep), 20.08.2016; all leg. S.Yu. Knyazev.

DISTRIBUTION. This species is widespread in European Russia, several Eastern European countries and NW Kazakhstan. In the Asian part of Russia, $B$. jawlowskii has recently been found introduced in anthropogenic and semi-anthropogenic habitats in the cities of Barnaul and Biysk, as well as on open man-made grounds in the Pervomaiskii District, all within the Altai Province, SW Siberia [Nefediev et al., 2014].

REMARKS. The Omsk Area has hitherto been a complete lacuna as regards the millipede fauna [Mikhaljova, Golovatch, 2001]. Brachyiulus jawlowskii is the first diplopod to be reported from the Omsk Area. As the above records concern only urban semi-natural habitats, they are likely to represent anthropochore introductions, while indigenous elements in the millipede fauna of the Omsk Area still remain unknown. Moreover, the occurrence of $B$. jawlowskii rather deep in the soil might be evidence of its special survival strategy during dry summers. This may also explain the superficial absence of millipedes from the Omsk Area, where special attention must be paid to soil sampling at such depths. Another species of this genus, B. bagnalli (Curtis, 1845), is also capable of getting deep in the soil [Tuf et al., 2015].

\section{Order GEOPHILOMORPHA \\ Family GEOPHILIDAE}

\section{Geophilus proximus C.L. Koch, 1847 Map 1.}

MATERIAL EXAMINED (69 specimens: 53 우, 16 juv. from 20 localities: all from Russia, Siberia, Omsk Area). 1 (ASU), Tevriz District, $12.2 \mathrm{~km}$ NE Ermilovka, $57^{\circ} 44^{\prime} 10^{\prime \prime} \mathrm{N}, 73^{\circ} 00^{\prime} 59^{\prime \prime} \mathrm{E}$, Tilia cordata forest, soil samples (litter), 28.05.2012; 1 \& (ASU) Bolshie Uki District, $2.2 \mathrm{~km}$ NW Firstovo, $57^{\circ} 03^{\prime} 03^{\prime \prime} \mathrm{N}, 72^{\circ} 51^{\prime \prime}$ 50 "E, dark coniferous Betula forest, soil samples (0-10 cm deep), 15.07.2013; 1 juv. (PSU), Tara District, $6.7 \mathrm{~km}$ NE Loskutovo, $56^{\circ} 50^{\prime} 46^{\prime \prime} \mathrm{N}, 74^{\circ} 07^{\prime} 59^{\prime \prime} \mathrm{E}$, mixed herbaceous meadow, soil samples (0-10 cm deep), 17.07.2013; 1 우 (OSPU), Bolshie Uki District, 1 $\mathrm{km} \mathrm{S}$ Firstovo, $57^{\circ} 01^{\prime} 44^{\prime \prime} \mathrm{N}, 72^{\circ} 52^{\prime} 58^{\prime \prime} \mathrm{E}$, set-aside with Urtica dioica, soil samples (0-10 $\mathrm{cm}$ deep), 18.07.2013; 2 우 (ASU), same District, $16.4 \mathrm{~km}$ E Firstovo, $57^{\circ} 05^{\prime} 57^{\prime \prime} \mathrm{N}, 72^{\circ} 38^{\prime} 03^{\prime \prime}$ E, flood meadow, soil samples $(10-20 \mathrm{~cm}$ deep $), 19.07 .2013 ; 2$ 우 (ASU), Sargatskoe District, $1.6 \mathrm{~km}$ NE Novopokrovka, 55 $43^{\prime 2} 2^{\prime \prime}$ $\mathrm{N}, 74^{\circ} 03^{\prime} 19^{\prime \prime} \mathrm{E}$, flood meadow, soil samples (0-20 cm deep), 22.06. 2014; 5 우 (ASU), same District, $3.8 \mathrm{~km}$ NE Zagotzerno, 55 $37^{\prime} 48^{\prime \prime} \mathrm{N}, 73^{\circ} 37^{\prime} 42^{\prime \prime} \mathrm{E}$, mixed herbaceous-sedge Betula forest, soil samples (0-20 cm deep), 23.06.2014; 3 우 (ASU), same District, $3.6 \mathrm{~km}$ SE Oktyabrskoe, $55^{\circ} 31^{\prime} 29^{\prime \prime} \mathrm{N}, 73^{\circ} 38^{\prime} 58^{\prime \prime} \mathrm{E}$, mixed herbaceous Betula forest, soil samples (10-20 cm deep), 23.06.2014; 2 우, 2 juv. (ASU), Omsk City, Omsk Regional Station of Young Naturalists, $54^{\circ} 58^{\prime} 51^{\prime \prime} \mathrm{N}, 73^{\circ} 18^{\prime} 12^{\prime \prime} \mathrm{E}$, mixed herbaceous Betula forest, soil samples (0-10 cm deep), 7.06.2015; 1 ㅇ, 1 juv. (PSU), Lyubinskii District, $2 \mathrm{~km} \mathrm{E} \mathrm{Chernoluchinskii,} 55^{\circ} 16^{\prime} 57^{\prime \prime} \mathrm{N}, 73^{\circ}$ $04^{\prime} 03^{\prime \prime} \mathrm{E}$, small herbaceous-grass Betula forest, soil samples (0-10 cm deep), 10.06.2015; 1 ( (ASU), Tavricheskoe District, 2 km NW Karpovka, $54^{\circ} 31^{\prime} 26^{\prime \prime} \mathrm{N}, 73^{\circ} 42^{\prime} 25^{\prime \prime} \mathrm{E}$, grass-mixed herbaceous steppe meadow, soil samples (0-10 cm deep), 20.06.2015; 2 우 (ASU), 2 우 (OSPU), Marianovka District, $2.9^{\mathrm{km} \mathrm{S}}$ Usovka, 54 $53^{\prime} 19^{\prime \prime} \mathrm{N}$, $72^{\circ} 39^{\prime} 12^{\prime \prime} \mathrm{E}$, grass-mixed herbaceous steppe meadow, soil samples (0-10 cm deep), 21.06.2015; 1 ㅇ (ASU), Cherlak District, $9.5 \mathrm{~km}$ SE Nikolaevka, $54^{\circ} 14^{\prime} 29^{\prime \prime} \mathrm{N}, 75^{\circ} 10^{\prime} 30^{\prime \prime} \mathrm{E}$, wormwood-fescue steppe, soil samples (10-20 cm deep), 27.06.2015; 3 오 (ASU), Kormilovka District, $7 \mathrm{~km}$ NW Kormilovka, $54^{\circ} 59^{\prime} 09^{\prime \prime} \mathrm{N}, 74^{\circ} 13^{\prime} 33^{\prime \prime} \mathrm{E}$, grassmixed herbaceous meadow, soil samples $(10-20 \mathrm{~cm}$ deep), 7.07. 2015; 1 오 (ASU), Omsk District, 2.4 km N Lugovaya, 55 $15^{\prime} 38^{\prime \prime} \mathrm{N}$, $73^{\circ} 14^{\prime} 10^{\prime \prime} \mathrm{E}$, steppe meadow, soil samples $(10-20 \mathrm{~cm}$ deep), 8.07.2015; 2 우 (ASU), same District, $3.5 \mathrm{~km}$ E Alekseevka, $55^{\circ} 19^{\prime} 21^{\prime \prime} \mathrm{N}, 73^{\circ} 25^{\prime} 53^{\prime \prime} \mathrm{E}$, sedge-grass Betula forest, soil samples (0-10 cm deep), 8.07.2015; 1 \% (ASU), Kormilovka District, 4.6 km SE Kormilovka, $54^{\circ} 58^{\prime} 38^{\prime \prime} \mathrm{N}, 74^{\circ} 08^{\prime} 53^{\prime \prime} \mathrm{E}$, mixed herbaceousgrass Betula forest, soil samples (10-20 cm deep), 9.07.2015; 1 , 2 juv. (PSU), Omsk City, "Sovetskii" Park, $55^{\circ} 01^{\prime} 33^{\prime \prime} \mathrm{N}, 73^{\circ} 16^{\prime}$ $31^{\prime \prime} \mathrm{E}$, Populus artificial stand edge, soil samples $(0-10 \mathrm{~cm}$ deep), 12.07.2015; 2 우, 3 juv. (PSU), Omsk City, "Sovetskii" Park, 55 $01^{\prime} 32^{\prime \prime} \mathrm{N}, 73^{\circ} 16^{\prime} 34^{\prime \prime} \mathrm{E}$, Betula, soil samples (10-20 cm deep), 12. 07.2015; 1 9 (ASU), Lyubinskii District, $1.5 \mathrm{~km}$ NW Politotdel, $55^{\circ} 13^{\prime} 23^{\prime \prime} \mathrm{N}, 73^{\circ} 08^{\prime} 32^{\prime \prime} \mathrm{E}$, Populus tremula \& Betula stand, soil samples (10-20 cm deep), 13.07.2015; 2 우 (OSPU), same District, $2.6 \mathrm{~km}$ NE Kochki, $55^{\circ} 06^{\prime} 02^{\prime \prime} \mathrm{N}, 72^{\circ} 42^{\prime} 42^{\prime \prime} \mathrm{E}$, mixed herbaceous Betula stand, soil samples (10-20 cm deep), 13.07.2015; 5 ㅇ (ZMUM), Azovo German National District, $2.5 \mathrm{~km} N$ Yuzhnoe, $54^{\circ} 02^{\prime} 11^{\prime \prime} \mathrm{N}, 74^{\circ} 01^{\prime} 42^{\prime \prime} \mathrm{E}$, grass-mixed herbaceous steppe meadow, soil samples (0-10 cm deep), 15.07.2015; 1 \%, 1 juv. (ASU), Tavricheskoe District, $3.2 \mathrm{~km}$ NW Karpovka, $54^{\circ} 31^{\prime} 38^{\prime \prime} \mathrm{N}, 73^{\circ} 41^{\prime}$ $34^{\prime \prime} \mathrm{E}$, mixed herbaceous meadow, soil samples (10-20 cm deep), 1.08.201; 2 우 (ASU), Moskalenki District, 1.6 km SW Nadezhdovka, $54^{\circ} 54^{\prime} 50^{\prime \prime} \mathrm{N}, 71^{\circ} 52^{\prime} 17^{\prime \prime} \mathrm{E}$, mixed herbaceous-grass Betula forest, soil samples (10-20 cm deep), 5.08.2015; 1 ๆ (OSPU), Marianovka District, $1.2 \mathrm{~km} \mathrm{SW}$ Usovka, $54^{\circ} 54^{\prime} 37^{\prime \prime} \mathrm{N}, 72^{\circ} 37^{\prime} 05^{\prime \prime}$ E, grass-mixed herbaceous Betula forest, soil samples $(0-10 \mathrm{~cm}$ deep), 10.08.2015; 1 (PSU), Omsk City, Omsk Regional Station of Young Naturalists, $54^{\circ} 58^{\prime} 50^{\prime \prime} \mathrm{N}, 73^{\circ} 18^{\prime} 10^{\prime \prime} \mathrm{E}$, steppe meadow, soil samples (0-10 cm deep), 6.06.2016; 3 우 (PSU), same locality, soil samples (10-20 cm deep), 7.06.2016; 4 juv. (PSU), Isilkul District, $4.6 \mathrm{~km}$ SE Solntsevka, 54 $58^{\prime} 20^{\prime \prime} \mathrm{N}, 71^{\circ} 22^{\prime} 16^{\prime \prime} \mathrm{E}$, mixed herbaceous-grass Betula forest, soil samples $(0-10 \mathrm{~cm}$ deep), 7.07.2016; 3 우, 2 juv. (PSU), same District, 2 km SE Boevoe, $54^{\circ} 54^{\prime} 42^{\prime \prime} \mathrm{N}, 71^{\circ} 28^{\prime} 38^{\prime \prime} \mathrm{E}$, mixed herbaceous Betula forest, soil samples (10-20 cm deep), 7.07.2016; all leg. S.Yu. Knyazev.

DISTRIBUTION. Being a trans-Palaearctic species, G. proximus has hitherto been recorded in western Siberia, Asian Russia from the Tyumen, Novosibirsk and Tomsk areas, as well as from the Altai Province [Nefediev et al., 2017].

REMARKS. This species is recorded herewith from the Omsk Area for the first time, obviously representing the only geophilomorph centipede species to occur there. The local populations are parthenogenetic, as are the others known from western Siberia. 


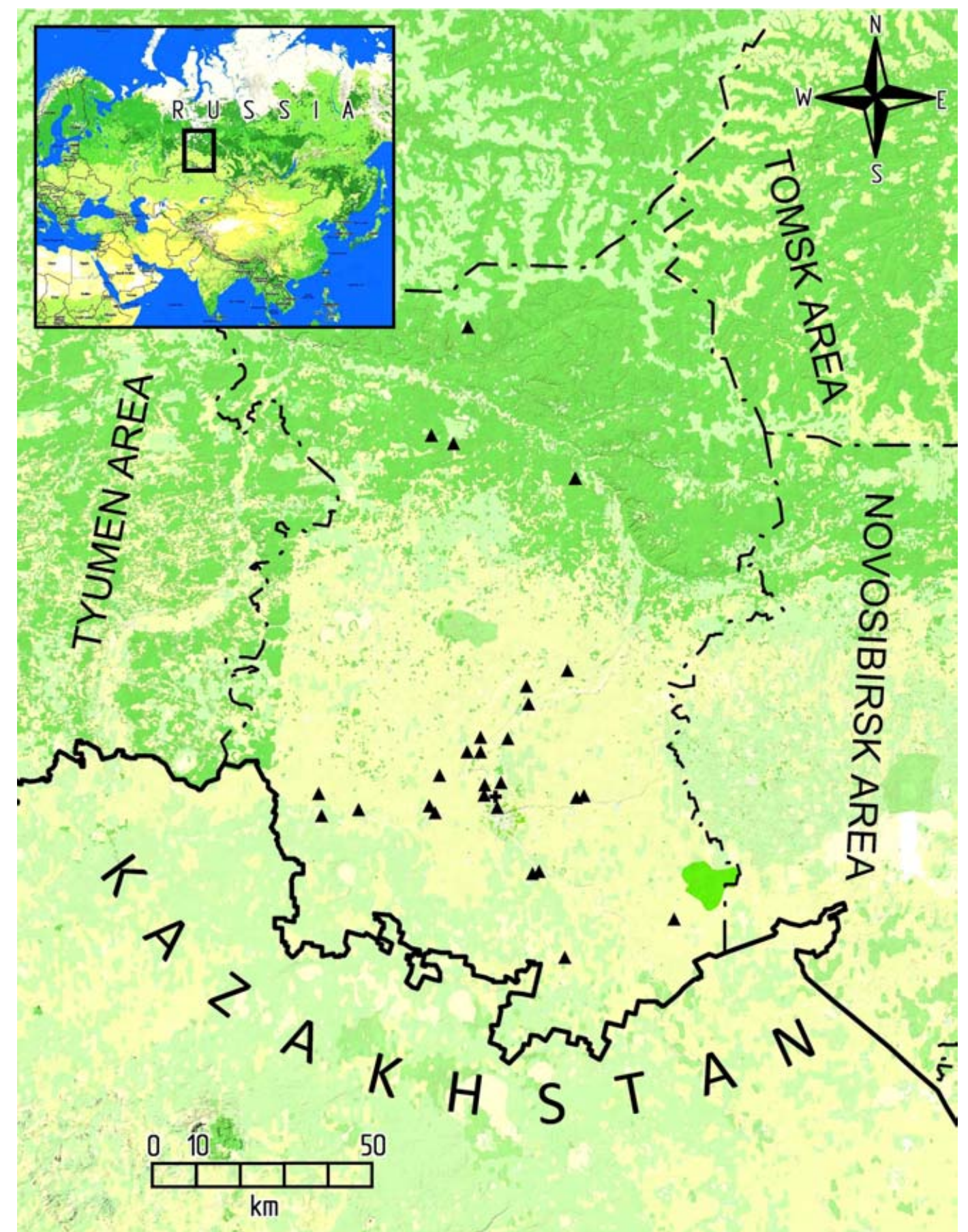

Map 1. Distribution of myriapods in the Omsk Area: cross - Brachyiulus jawlowskii; filled triangle - Geophilus proximus. Карта 1. Распространение многоножек в Омской области: крест - Brachyiulus jawlowskii; треугольник — Geophilus proximus.

Order LITHOBIOMORPHA Family LITHOBIIDAE

Hessebius sp.

Map 2.

MATERIAL EXAMINED. 1 9 (PSU), Russia, Siberia, Omsk Area, Omsk City, Omsk Regional Station of Young Naturalists, $54^{\circ} 58^{\prime} 50^{\prime \prime} \mathrm{N}, 73^{\circ} 18^{\prime} 10^{\prime \prime} \mathrm{E}$, steppe meadow, soil samples $(0-10 \mathrm{~cm}$ deep), 6.06.2016, leg. S.Yu. Knyazev.

DISTRIBUTION. The genus Hessebius has previously been known ranging from eastern Ukraine and the Caucasus in the west, through western and Central Asia (Turkey, Tajikistan, Kirgizstan and eastern Kazakhstan), to SE China in the east [Zalesskaja, 1978; Pei et al., 2010; Farzalieva, 2017]. In Asian Russia, it has 
recently been recorded from xerophytic habitats on the southern slope of the Irtysh River root terrace in the Tyumen Area [Sergeeva, 2013].

REMARKS. This genus is new to the fauna of the Omsk Area and its species tends to dwell there in dry steppe habitats. The species identity of the new record is to be delayed pending a revision of the variation range of $H$. multicalcaratus Folkmanová, 1958.

\section{Lithobius (Monotarsobius) curtipes C.L. Koch, 1847 Map 2.}

MATERIAL EXAMINED (17 specimens: $7 \sigma^{\top} \sigma^{7}, 8$ 우, 2 juv. from 10 localities: all from Russia, Siberia, Omsk Area). 1 o (PSU), Sedelnikovo District, $22.3 \mathrm{~km}$ NE Litkovka, 57 $23^{\prime} 32^{\prime \prime} \mathrm{N}$, $75^{\circ} 23^{\prime} 42^{\prime \prime} \mathrm{E}$, Populus tremula, Betula \& dark coniferous forest, soil samples (litter), 30.05.2012; 2 O $^{7} \mathrm{O}^{7}$ (PSU), Bolshie Uki District, $2.5 \mathrm{~km} \mathrm{NW}$ Bolshie Uki, $56^{\circ} 58^{\prime} 25^{\prime \prime} \mathrm{N}, 72^{\circ} 35^{\prime} 18^{\prime \prime} \mathrm{E}$, mixed herbaceous meadow, soil samples (10-20 cm deep), 16.07.2013; 1 ,+ 1 juv. (PSU), Tara District, $6.7 \mathrm{~km}$ NE Loskutovo, $56^{\circ} 50^{\prime} 46^{\prime \prime} \mathrm{N}$, $74^{\circ} 07^{\prime} 52^{\prime \prime} \mathrm{E}$, mixed herbaceous meadow, soil samples $(0-10 \mathrm{~cm}$ deep), 17.07.2013; $1 \mathrm{O}^{7}$ (PSU), Bolshie Uki District, $5 \mathrm{~km} \mathrm{NW}$ Forpost, $56^{\circ} 49^{\prime} 27^{\prime \prime} \mathrm{N}, 72^{\circ} 07^{\prime} 10^{\prime \prime} \mathrm{E}$, Populus tremula \& Betula forest, soil samples $\left(0-10 \mathrm{~cm}\right.$ deep), 23.07.2013; $1 \mathrm{O}^{\mathrm{T}}$ (OSPU), Znamenskoe District, $2.4 \mathrm{~km} \mathrm{NW}$ Kochukovo, $57^{\circ} 12^{\prime} 41^{\prime \prime} \mathrm{N}, 73^{\circ} 47^{\prime}$ $33^{\prime \prime}$ E, flood meadow, soil samples $(0-10 \mathrm{~cm}$ deep), 27.07.2013; 1 o (PSU), Tevriz District, $6 \mathrm{~km} \mathrm{~N}$ Tevriz, $57^{\circ} 34^{\prime} 23^{\prime \prime} \mathrm{N}, 72^{\circ} 21^{\prime} 38^{\prime \prime} \mathrm{E}$, floodplain of Irtysh River, flood meadow, soil samples $(0-10 \mathrm{~cm}$ deep), 12.07.2014; 1 ㅇ (OSPU), same District, $5.1 \mathrm{~km} \mathrm{~N}$ Belyi Yar, $57^{\circ} 38^{\prime} 01^{\prime \prime} \mathrm{N}, 72^{\circ} 23^{\prime} 29^{\prime \prime} \mathrm{E}$, dark coniferous green mosses forest edge, soil samples (0-20 cm deep), 12.07.2014; $1 \mathrm{O}^{7}, 2$ 우 (ZMUM), same District, $6.2 \mathrm{~km}$ NW Ekaterinovka, $57^{\circ} 38^{\prime} 18^{\prime \prime} \mathrm{N}, 72^{\circ} 44^{\prime} 20^{\prime \prime} \mathrm{E}$, Pinus sylvestris \& Betula forest edge, soil samples $(0-20 \mathrm{~cm}$ deep), 13.07.2014; 1 + (PSU), Lyubinskii District, $2 \mathrm{~km}$ E Chernoluchinskii, $55^{\circ} 16^{\prime} 51^{\prime \prime} \mathrm{N}, 73^{\circ} 04^{\prime} 03^{\prime \prime} \mathrm{E}$, small herbaceous-grass Betula forest, soil samples (0-10 cm deep), 10.06.2015; $2 \mathrm{O}^{7} \mathrm{O}^{7}, 1$ ㅇ, 1 juv.

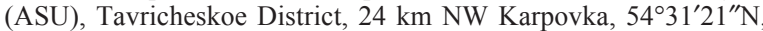
$73^{\circ} 20^{\prime} 56^{\prime \prime} \mathrm{E}$, Betula stand, soil samples (10-20 cm deep), 20 06.2015; all leg. S.Yu. Knyazev.

DISTRIBUTION. Being a trans-Palaearctic polyzonal species, $L$. (M.) curtipes is highly widespread in European Russia as far as the Caucasus and the Urals [Farzalieva, 2008], while in western Siberia it has previously been known from the Novosibirsk, Tomsk and Tyumen areas, as well as from the Altai Province [Nefediev et al., 2016]; also known from eastern Siberia [Rybalov, 2002; Vorobiova et al., 2002] and N Mongolia [Poloczek et al., 2016].

REMARKS. This species is also new to the Omsk Area.

Lithobius (Monotarsobius) insolens Dányi et Tuf, 2012

\section{Map 2.}

MATERIAL EXAMINED (10 specimens: $4 \sigma^{\top} \sigma^{\top}, 3$ 우, 3 juv. from 4 localities: all from Russia, Siberia, Omsk Area). $1 \sigma^{7}$ (PSU), Lyubinskii District, $2 \mathrm{~km}$ E Chernoluchinskii, $55^{\circ} 16^{\prime} 51^{\prime \prime} \mathrm{N}, 73^{\circ} 04^{\prime}$ $03^{\prime \prime}$, small herbaceous-grass Betula forest, soil samples $(0-10 \mathrm{~cm}$ deep), 10.06.2015; 1 ㅇ (ZMUM), Omsk City, "Sovetskii" Park, $55^{\circ} 01^{\prime} 33^{\prime \prime} \mathrm{N}, 73^{\circ} 16^{\prime} 31^{\prime \prime} \mathrm{E}$, Populus artificial stand edge, soil sam-

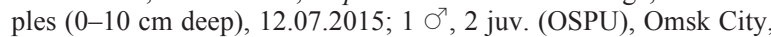
"Sovetskii" Park, $55^{\circ} 01^{\prime} 32^{\prime \prime} \mathrm{N}, 73^{\circ} 16^{\prime} 34^{\prime \prime} \mathrm{E}$, Betula, soil samples (10-20 cm deep), 12.07.2015; 2 +क (PSU), Isilkul District, $4.6 \mathrm{~km}$ SE Solntsevka, $54^{\circ} 58^{\prime} 20^{\prime \prime} \mathrm{N}, 71^{\circ} 22^{\prime} 16^{\prime \prime} \mathrm{E}$, mixed herbaceous-grass Betula forest, soil samples (0-10 cm deep), 7.07.2016; $1 \sigma^{7}, 1$ juv. (ZMUM), $1 \sigma^{\top}$ (ASU), Isilkul District, 2 km SE Boevoe, 54 $54^{\prime}$ $42^{\prime \prime} \mathrm{N}, 71^{\circ} 28^{\prime} 38^{\prime \prime} \mathrm{E}$, mixed herbaceous Betula forest, soil samples (10-20 cm deep), 7.07.2016; all leg. S.Yu. Knyazev.

DISTRIBUTION. Being a Central Asian species, $L$. (M.) insolens has previously been recorded only from the Dzhungarskii Alatau and Tarbagatai mountains, eastern Kazakhstan [Farzalieva, 2006: as L. (M.) insolitus].

REMARKS. The above record of $L$. (M.) insolens in the Omsk Area is new to the Russian list of lithobiomorph centipedes.

\section{Lithobius (Ezembius) princeps Stuxberg, 1876} Map 2.

MATERIAL EXAMINED. $1 \sigma^{7}$ subadult (PSU), Russia, Siberia, Omsk Area, Tevriz District, $12.2 \mathrm{~km}$ NE Ermilovka, 57 $44^{\prime}$ $10^{\prime \prime} \mathrm{N}, 73^{\circ} 00^{\prime} 59^{\prime \prime} \mathrm{E}$, Tilia cordata forest, soil samples (litter), 28.05.2012, leg. S.Yu. Knyazev.

DISTRIBUTION. This species has hitherto been known only from the type locality in the Yenisei River valley, Krasnoyarsk Province, eastern Siberia, as well as from the valley of Irtysh River, Tyumen Area, western Siberia [Stuxberg, 1876; Zalesskaja, 1978; Eason, 1976; Sergeeva, 2013].

REMARKS. This is the first record of the species in the Omsk Area, where it seems to be quite rare and has been found in a single locality (lime forest).

\section{Lithobius (Ezembius) proximus Sseliwanoff, 1878} Map 2.

MATERIAL EXAMINED (5 specimens: 2 ㅇ, 3 juv. from 3 localities: all from Russia, Siberia, Omsk Area). 1 ㅇ, 1 juv. (PSU), Bolshie Uki District, $5 \mathrm{~km}$ NW Forpost, $56^{\circ} 49^{\prime} 27^{\prime \prime} \mathrm{N}, 7^{\circ} 07^{\prime} 10^{\prime \prime} \mathrm{E}$, Populus tremula \& Betula forest, soil samples (0-10 cm deep), 23.07.2013; 1 juv. (PSU), Krutinka District, 4.5 km NW Krasnyi Pakhar, 56 $07^{\prime} 04^{\prime \prime} \mathrm{N}, 71^{\circ} 27^{\prime} 26^{\prime \prime} \mathrm{E}$, Populus tremula \& Betula forest, soil samples (0-20 cm deep), 25.06.2014; all leg. S.Yu. Knyazev.

DISTRIBUTION. Being a widespread Siberian boreal species, $L$. (E.) proximus penetrates as far west of the Urals as the Samara Area and the republics of Mari El, Tatarstan and Bashkortostan, and as far east as the Maritime Province, Sakhalin and the Kuriles [Zalesskaja, 1978; Farzalieva, Esyunin, 2008].

REMARKS. The above records of the species are new to the Omsk Area. The juvenile specimen (= subadult female) from the Krutinka District with $3+3$ gonopodal spurs is obviously an aberrant specimen. In the study area, $L$. (E.) proximus tends to dwell in smallleaved forests.

\section{Lithobius (Monotarsobius) sp.}

MATERIAL EXAMINED ( 2 specimens: $10^{7}$ and 1 juv. from 2 localities: all from Russia, Siberia, Omsk Area). $1 \sigma^{7}$ (PSU), Tevriz District, $12.2 \mathrm{~km}$ NE Ermilovka, 57 $44^{\prime} 10^{\prime \prime} \mathrm{N}, 73^{\circ} 00^{\prime} 59^{\prime \prime} \mathrm{E}$, Tilia cordata forest, soil samples (litter), 28.05.2012; 1 juv. (PSU),

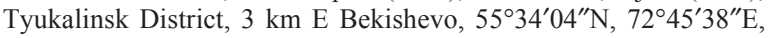
Populus tremula \& Betula stand, soil samples $(0-20 \mathrm{~cm}$ deep), 26.06.2014; all leg. S.Yu. Knyazev.

REMARKS. These specimens are most likely to belong to $L$. (M.) curtipes or L. (M.) insolens. 


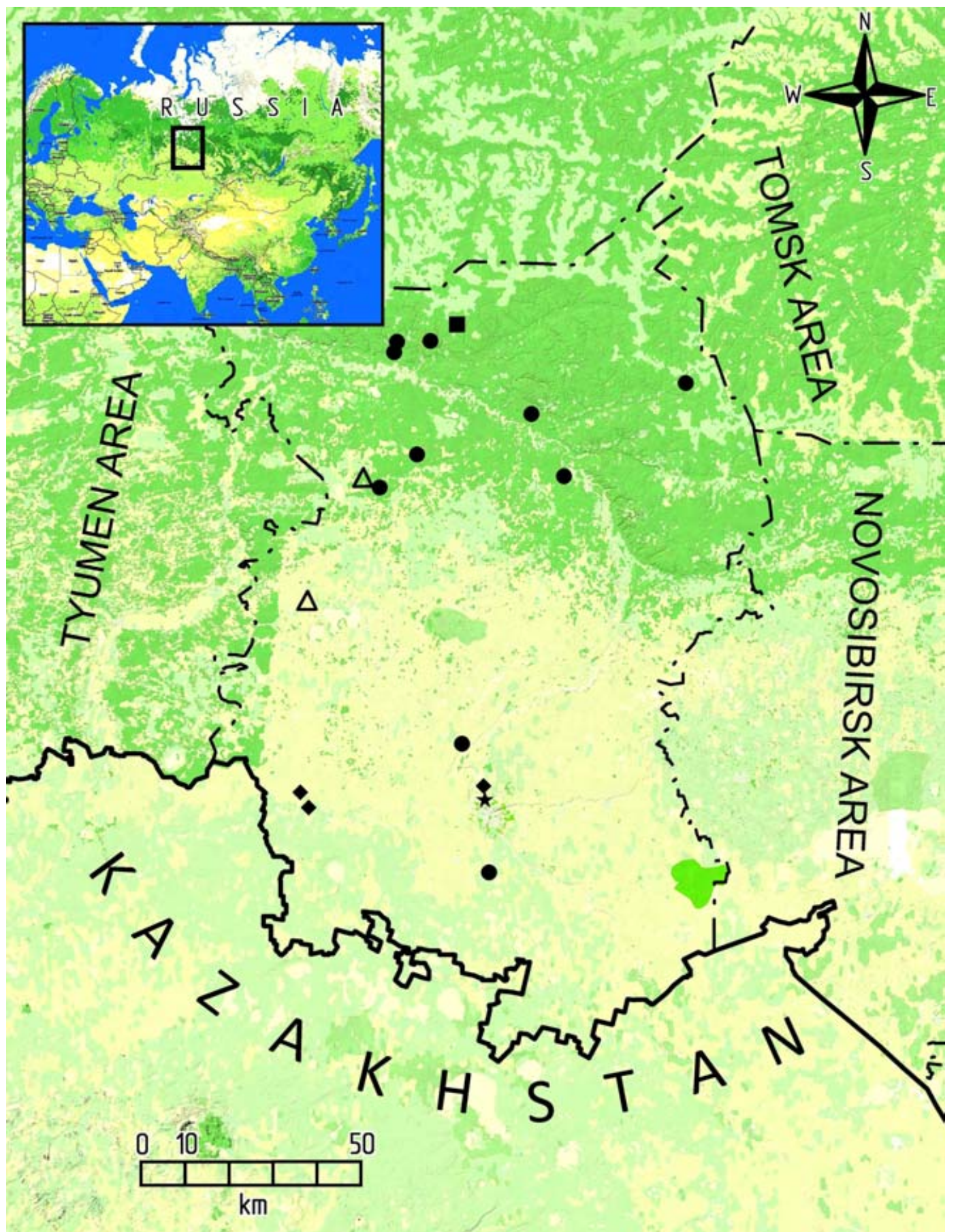

Map 2. Distribution of lithobiomorph centipedes in the Omsk Area: asterisk - Hessebius sp.; circle - Lithobius (Monotarsobius) curtipes; diamond - L. (M.) insolens; square - L. (Ezembius) princeps; empty triangle - L. (E.) proximus.

Карта 2. Распространение многоножек-костянок в Омской области: звезда - Hessebius sp.; круг — Lithobius (Monotarsobius) curtipes; ромб — L. (M.) insolens; квадрат — L. (Ezembius) princeps; прозрачный треугольник - L. (E.) proximus.

\section{Conclusions}

Given the above new information, from a myriapodological point of view, the Omsk Area, SW Siberia, Russia, which has hitherto remained a complete lacuna, actually demonstrates a surprisingly poor fau- na. Both the total absence of indigenous Diplopoda (except for Brachyiulus jawlowskii Lohmander, 1928, an anthropochore introduction found only in the city of Omsk) and the very low species richness of Chilopoda suggest the prevalence of historical rather than ecological factors which might have affected their faunogene- 
sis. Thus, taking spiders as an example, due to the likewise low general vagility of the group, the penetration of numerous spider species into Siberia from the east is believed to have been prevented by the vast flooded areas of the West Siberian Plain during the Pleistocene glacial periods [Esyunin, 2005]. The Ural Mountains appear to represent a sharp zoogeographical boundary for the European fauna of Diplopoda to the east [Golovatch, 1984]. Such historical and geographical backgrounds seem to have played the crucial roles in the distribution of non-flying invertebrates in the study area.

At present, only seven species from four genera and three families of Myriapoda are known to occur in the Omsk Area. The millipede genus Brachyiulus Berlese, 1884, the species B. jawlowskii Lohmander, 1928, and the family Julidae are all new to the study area. The species diversity of geophilomorph centipedes is restricted to a single species, Geophilus proximus C.L. Koch, 1847, which, like generally in Siberia, is represented there by parthenogenetic populations, and, together with the genus Geophilus Leach, 1814 and the family Geophilidae, is also reported from the Omsk Area for the first time. The most important amongst the new faunistic records of lithobiomorph centipedes are as follows: Lithobius (Monotarsobius) insolens Dányi et Tuf, 2012 is new to Russia; the genus Hessebius Verhoeff, 1941, the genus Lithobius Leach, 1814, with its subgenera Monotarsobius Verhoeff, 1905 and Ezembius Chamberlin, 1919, as well as L. (M.) curtipes C.L. Koch, 1847, L. (E.) princeps Stuxberg, 1876 and L. (E.) proximus Sseliwanoff, 1878, together with the family Lithobiidae they belong to, are also new to the Omsk Area.

The presence in the Omsk Area of another few widespread Siberian or anthropochore myriapod species also seems very likely: $L$. (E.) sibiricus Gerstfeldt, 1858 , which is one of the most widespread indigenous lithobiomorph centipedes in Siberia, as well as the subcosmopolitan L. (L.) forficatus (Linnaeus, 1758) and Lamyctes (Lamyctes) emarginatus (Newport, 1844), both introduced to many urban areas in SW Siberia [Nefediev et al., 2016]. This may also concern a couple of geophilomorph centipedes from the family Schendylidae, such as Escaryus japonicus Attems, 1927 and E. retusidens Attems, 1904.

ACKNOWLEDGEMENTS. We are most grateful to S.I. Golovatch (Moscow, Russia) who kindly checked the English of an advanced draft. The results were obtained within the framework of the state task No. 6.2884.2017/4.6 Ministry of Education and Science of Russian Federation.

\section{References}

Esyunin S.L. 2005. [The fauna structure and chorology of spiders (Aranei) of the Urals and Cisuralia]. Abstract of the Thesis of
Doctor Biological Sci. Degree. Moscow. 43 p. [in Russian]. Farzalieva G.Sh. 2006. New species of the lithobiid genus Lithobius (Monotarsobius) (Chilopoda: Lithobiomorpha: Lithobiidae) from eastern Kazakhstan // Arthropoda Selecta. Vol.15. No.2. P.99-117.

Farzalieva G.Sh. 2008. [The fauna and chorology of Myriapoda from the Urals and Cisuralia]. PhD Thesis. Perm State University. 189 p. [in Russian].

Farzalieva G.Sh. 2017. [New species of lithobiomorph centipedes of the genus Hessebius Verhoeff, 1941 (Lithobiomorpha, Lithobiidae) from eastern Kazakhstan] // Zoologicheskii Zhurnal. T.96. No.1. P.30-36 [in Russian, with English summary].

Farzalieva G.Sh., Esyunin S.L. 2008. A review of the centipede (Lithobiomorpha, Henicopidae, Lithobiidae) fauna of the Urals and Cis-Ural Area // Entomological Review. Vol.88. No.5. P.598-623.

Ghilarov M.S. 1987. [Censuses of larger invertebrates (mesofauna)] // Kolichestvennye metody v pochvennoi zoologii. Moscow: Nauka Publ. P.9-26 [in Russian].

Golovatch S.I. 1984. [The distribution and faunogenesis of millipedes of the USSR European part] // Chernov Yu.I. (ed.). Faunogenez i filotsenogenez. Moscow: Nauka Publ. P.92-138 [in Russian].

Mikhaljova E.V., Golovatch S.I. 2001. A review of the millipede fauna of Siberia (Diplopoda) // Arthropoda Selecta. Vol.9. No.2. P.103-118 (for 2000).

Nefediev P.S., Nefedieva J.S., Dyachkov Yu.V. 2014. A review of the anthropochore millipede fauna of Asian Russia, with new records from the Altai Province, Siberia (Diplopoda) // Arthropoda Selecta. Vol.23. No.4. P.337-345.

Nefediev P.S., Tuf I.H., Farzalieva G.Sh. 2016. Centipedes from urban areas in southwestern Siberia, Russia (Chilopoda). Part 1. Lithobiomorpha // Arthropoda Selecta. Vol.25. No.3. P.257-266.

Nefediev P.S., Tuf I.H., Farzalieva G.Sh. 2017. Centipedes from urban areas in southwestern Siberia, Russia (Chilopoda). Part 2. Geophilomorpha // Arthropoda Selecta. Vol.26. No.1. P.8-14.

Pei S., Ma H., Zapparoli M., Zhu M. 2010. A review of the Chinese species of Hessebius Verhoeff, 1941 (Chilopoda: Lithobiomorpha: Lithobiidae) // Zootaxa. Vol.2631. P.51-61.

Poloczek A., Pfeiffer M., Schneider R., Müchlenberg M. 2016. The Chilopoda (Myriapoda) of the Khentey-Mountain Range, Northern Mongolia. Communities of different forest-types under a varying fire regime // European Journal of Soil Biology. Vol.74. P.114-120.

Rybalov L.B. 2002. [Zonal and landscape changes in soil invertebrate populations in a near-Yenisei River region of Middle Siberia and the role of temperature adaptations in the meridional (zonal) distribution of invertebrates] // Russian Entomological Journal. Vol.11. No.1. P.77-86 [in Russian, with English summary].

Sergeeva E.V. 2013. [Biotopic distribution and the numbers of centipedes (Chilopoda) in the Irtysh Valley of western Siberia, Russia] // Euroasian Entomological Journal. Vol.12. No.6. P.529-533 [in Russian, with English summary].

Tuf I.H., Chmelík V., Dobroruka I., Hábová L., Hudcová P., Šipoš J., Stašiov S. 2015. Hay-bait traps are useful tool for sampling of soil dwelling millipedes and centipedes // ZooKeys. Vol.510. P.197-207.

Vorobiova I.G., Rybalov L.B., Rossolimo T.E., Zalesskaja N.T. 2002. [Zonal and landscape distribution of the myriapod fauna and populations (Myriapoda) in the Yenisei River basin] // Izuchenie, sokhranenie i vosstanovlenie bioraznoobraziya ekosistem na Yeniseiskom ekologicheskom transekte: Zhivotnyi mir, etno-ekologicheskie issledovniya, 2. Moscow: IPEE RAN Publ. P.60-71 [in Russian].

Zalesskaja N.T. 1978. [Identification book of the lithobiomorph centipedes of the USSR]. Moscow: Nauka Publ. 212 p. [in Russian].

Responsible editor S.I. Golovatch 